University of Nebraska - Lincoln

DigitalCommons@University of Nebraska - Lincoln

$12-1-1915$

\title{
A Brief Sketch of the Life and Work of Charles Edwin Bessey
}

Raymond J. Pool

University of Nebraska

Follow this and additional works at: https://digitalcommons.unl.edu/bioscisystematics

Part of the Botany Commons, Higher Education Commons, and the Science and Mathematics Education Commons

Pool, Raymond J., "A Brief Sketch of the Life and Work of Charles Edwin Bessey" (1915). Papers in Systematics \& Biological Diversity. 17.

https://digitalcommons.unl.edu/bioscisystematics/17

This Article is brought to you for free and open access by the Papers in the Biological Sciences at DigitalCommons@University of Nebraska - Lincoln. It has been accepted for inclusion in Papers in Systematics \& Biological Diversity by an authorized administrator of DigitalCommons@University of Nebraska - Lincoln. 


\section{AMERICAN \\ JOURNAL OF BOTANY}

VOL. II

DeCEMBer, 1915

No. 10

A BRIEF SKETCH OF THE LIFE AND WORK OF CHARLES EDWIN BESSEY

(WITH PORTRAIT)

Raymond J. Pool

Charles Edwin Bessey, professor of botany and head of the department of botany in the University of Nebraska since I 884 and a conspicuous figure in American science and education, passed away at his home in Lincoln on February 25, I915, after a critical illness of four weeks.

The Bessey family is of French extraction, the original form of the name being Bessé. The tradition is that the early members of the family, who were Huguenots, were compelled on account of religious persecution to flee to England from the old home near Strassburg in Alsace. This exodus occurred in the latter part of the seventeenth century after which the "y" was added to the name.

The Besseys remained in England for several generations. Among the first of the family to come to America was Jacob Bessey who, about the middle of the eighteenth century, emigrated from England.

Jacob Bessey married and settled near Doylestown, Pennsylvania. One of the sons of this union was Michael, who was a weaver by trade. This son married Mary Wismar, a descendant of a family from the Palatinate on the Rhine. Michael and Mary Bessey were the parents of Adnah Bessey who was born in eastern Pennsylvania in I812. In I832 Adnah Bessey's family with many others from the vicinity of his home migrated westward and settled in Wayne County, Ohio. Adnah Bessey married Margaret Ellenberger. Emmanuel Ellenberger, the father, died when Margaret was but a young girl and the widowed mother married again. Margaret's stepfather was Jacob Kimmel, a widower with a large family. Margaret was accordingly

[The Journal for November (2: 429-504) was issued Dec. I6, I9I5.] 


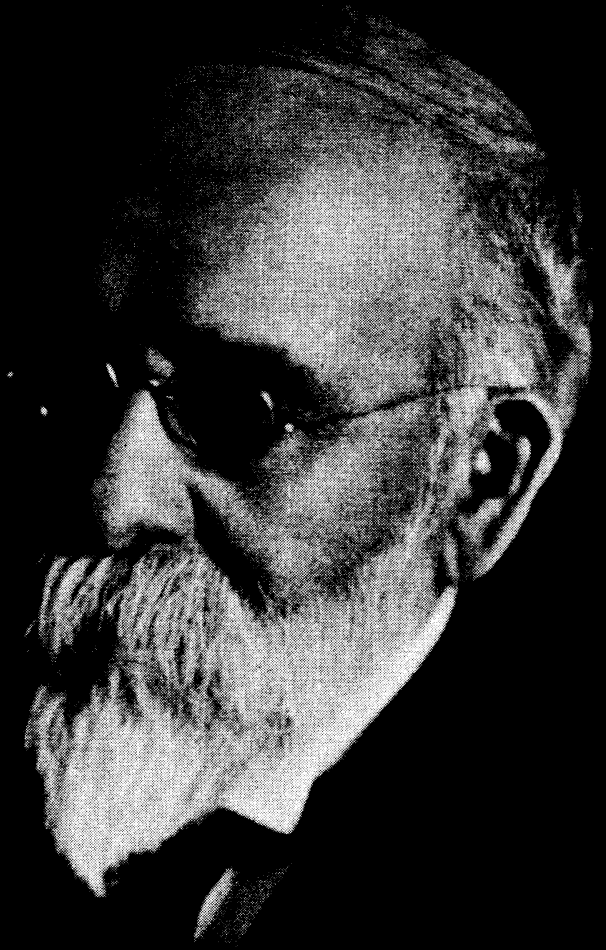

Qhadestokery 
"put out to live" with James McKinly and wife, an estimable couple who had also migrated from Pennsylvania to Ohio. This young lady was sent by her foster parents to a school which happened to be taught by Adnah Bessey, and some time later (I84I) teacher and pupil were married. Adnah Bessey and Margaret Ellenberger Bessey were the parents of Charles Edwin Bessey, who was born in a log house on a farm in Milton Township, Wayne County, Ohio, May 2I, I845. Much of the early education of Charles, the boy, was received under the direct attention and supervision of Adnah, the father. In his seventeenth year he received a certificate to teach school. He did not teach at that time, however, as he,had made all arrangements to enter the academy at Seville (Ohio) in order to fit himself for college. His educational training was interrupted soon after this by his father's ill health, but even then he attended the district school and studied algebra by himself. His father died in 1863 and that fall Charles attended the academy for five weeks. He then began teaching at Wadsworth, Ohio, where he remained for a term of four months. Following this (March, I864) he again entered the academy where he studied for two months, when the breaking up of the school precipitated another halt in the young man's educational career.

After several years of broken but persistent preparation in the country school and academy young Bessey entered the freshman class of Michigan Agricultural College in July, I866. He completed his college course at the age of twenty-four and graduated from the college with the degree of bachelor of science, November I0, I869.

When Bessey entered the college he firmly intended to return home to follow the profession of civil engineering or surveying. But he came to love the plants of the fields and forests. Finally his marked attention to such things became noticeable to others; for, after two years or so in college, the President (Abbott) and some of the professors (especially Prentiss) advised him to specialize in botany. At first the advice was rejected. But after weeks of reflection the young man found that his inclination had changed from engineering to botany.

Immediately after graduation Bessey was awarded an assistantship in horticulture and was placed in charge of the greenhouse at the Michigan Agricultural College. This position was held for a very short time because in December of that year (I869) the offer of an instructorship in botany and horticulture came from the Iowa State 
College of Agriculture at Ames. The call was accepted and he began his work at Ames, in February, I87o. An interesting point of historical note is seen in the fact that he attended and took part in the first Farmers' Institute held in Iowa; this was during the winter of 1870-1871. These were among the very first meetings of the kind ever held in any part of the United States. It also appears that he was the guiding spirit in the founding of the old (the first) Iowa Academy of Sciences. He was presidept of this organization in I875 and was re-elected regularly for several years.

Bessey was elected to membership in the American Association for the Advancement of Science at the Dubuque, Iowa, meeting in August, I872. This was the first occasion of his meeting with Dr. Asa Gray, who was then the retiring president of the Association. Here he also met Dr. How, Dr. Winchell, M. S. Bebb, and others who were to be some of his closest scientific friends and co-laborers for many years. The first fruits of this acquaintance with Gray were gathered during that winter of $1872-1873$ when he spent the long vacation of three months at Harvard University studying under Professor Gray. Under the watchful eye and kindly direction of the great botanist he laid the foundations of his knowledge of systematic botany especially in its philosophical aspects. The genial physician led the young man beyond the threshold of a "life among species and phyla" which was probably Dr. Bessey's most constant scientific enjoyment. Bessey returned for another period of study at Harvard in the winter of I $875-1876$.

In 1872 he received the degree of master of science from his alma mater and was promoted to a full professorship at Ames. In November, I873, he was offered the chair of botany, zoology, horticulture and pomology but this was refused. Later he was made professor of botany and zoology.

Early in the year 1874, at the suggestion of Dr. Gray, President Gilman, of the University of California, wrote to Professor Bessey asking him to give his views in regard to certain problems relating to agricultural education then demanding solution. His reply, along with those from Louis Agassiz, Andrew D. White, Samuel W. Johnson and others, was printed in a bulletin issued in the spring of 1874 by the University of California under the title: "Recent Information respecting Agricultural Education Elsewhere." This correspondence led to an invitation from President Gilman to Professor Bessey to go 
to California to give a series of botanical lectures in the university the following winter. The invitation was accepted and resulted in the appointment of Professor Bessey as a temporary "Lecturer on Botany."

In I879 the University of Iowa conferred the degree of doctor of philosophy upon Professor Bessey in recognition of his publications in botany and as a partial reward for what he had already accomplished for the state of Iowa.

After having served the state of Iowa and its Agricultural College faithfully and efficiently for a period of 'fifteen years there came in June, I884, notification that he had been'elected professor of botany in the University of Nebraska. He went to Lincoln but found nothing in botany at the institution that had called him, and he was reluctant to leave the accumulation of his labors at Ames to go to a new state to build up another department from the very beginning. So he declined. A second offer was made in August of the same year. After another trip to Lincoln and a consultation with the regents this position was accepted and his inaugural address was delivered in September, I 884 .

In Nebraska he began at once to collect data with reference to Nebraska grasses and the other plants of the state, and to make addresses. With the late Governor Furnas he organized the first series of Farmers' Institutes, which thereafter were periodically enlivened by his presence.

Bessey was a power among his fellow scientists, who were to be found in all parts of the world. From the time he first met Gray at Dubuque he seldom missed one of the annual gatherings, and he always took a keen interest in the administration of the various societies and in the scientific programs. The esteem of his associates was often reflected by the offices to which he was elected. In 1872 he became a member of the American Association and in I880 was elected a fellow in the same. In I 889 he was president of the Society for the Promotion of Agricultural Science, and also of the Western Society of Naturalists. He was vice-president of the American Association and chairman of Section C (botany) in 1893, I894, 1902, and 1907. He was also a charter member of the Botanical Society of America, of which he was president in 1895 . That same year he was also president of the department of science of the National Educational Association. He was chosen to be botanical editor of 
the American Naturalist in I880, a position which he held until I 897 when on invitation he accepted a similar position on the staff of Science.

The crowning scientific honor came at the Minneapolis meeting of the American Association for the Advancement of Science in I9I0I9II, when he was elected president. The following winter (I9III9I2) at Washington, D. C., he presided over the deliberations of this organization. When he returned to Lincqln after the meetings he was given an ovation by the students, faculty and the regents in the university chapel. The next winter (1912-I9I3) at the Cleveland meeting of the Association Dr. Bessey gave his address as retiring president. The paper which he read at that time was entitled: "Some of the Next Steps in Botanical Science."

Bessey was one of the pioneers who did much to lay the foundations of the present superstructure of American botany. The training with Gray naturally increased his love for taxonomy which is reflected in many of his publications. But he was thinking of other phases of botany also and some of his early papers show that he took advanced ground as to what should constitute the content of botany. In his paper on "The Diseases of Plants" (I882) we have abundant evidence that he was doing more than recording species and making herbaria. At this time the heterecious nature of rusts was not accepted by all botanists as conclusively demonstrated but Bessey felt that De Bary's conclusions were correct. The comments upon bacteria as diseaseproducing organisms are also interesting.

When in the early eighties the United States Department of Agriculture was considering the proposition to establish federal aid for state agricultural experiment stations he was consulted in regard to the wording of a bill for that purpose. He plunged into this work with the usual readiness and vigor and he finally wrote the paragraph defining the duties of such experiment stations verbatim as it was adopted later and became a part of the law known as the Hatch Act. $\mathrm{He}$ also wrote the first and second annual reports of the Agricultural Experiment Station of Nebraska in I 888 and I889, and from that time he did not cease to concern himself actively with the progress of these institutions which were to become important seats of learning and research throughout the country.

Much of the time that Dr. Bessey gave to study and writing was devoted to a painstaking survey of the structure and evolution of all 
of the main groups of the plant world. This monumental work was begun many years ago, the first paper in the series dealing in particular with the higher plants being entitled: "The Phylogeny and Taxonomy of the Angiosperms" which was read as the address of the retiring president of the Botanical Society of America at its third annual meeting at Toronto, Canada, August I7, I897. This paper contains a further statement of the thought and principles of a still earlier production-"Evolution and Classification"-which was given as the vice-presidential address of the chairman of the botanical section of the American Association at the Madison, Wisconsin, meeting in I893. For a quarter of a century Profesşor Bessey worked upon the "phyletic idea" in taxonomy, the above papers being among the earlier ones upon that subject. His last paper entitled: "The Phylogenetic Taxonomy of Flowering Plants" was one of a memorable series of papers read by invitation at the Twenty-fifth Anniversary Celebration of the Missouri Botanical Garden, at St. Louis, October I5, I9I4. The gathering at St. Louis at that time was his last meeting with the botanists of America.

But after all has been said about all of the other features of this great man's life we still must conclude that the most powerful and far-reaching effects of his captivating magnetism were recorded in the classroom, in the laboratory, in the college and in the university as a teacher and guide for the young. Professor Bessey utilized this potential to the limit, for he was one of the greatest teachers that the world has known. His powerful presentation of subject matter in the classroom was magnified by a personality which, because of its quaint paternal cordiality, won the admiration of thousands of students.

His lectures, delivered with a heavy clear voice and in non-technical phraseology, were always illustrated by means of quickly executed blackboard sketches which served at once to portray morphological features graphically and to drive home to the students' understanding exactly what he was talking about. He was so skilled with this method that he seldom used charts or diagrams prepared before class time. His small alarm clock and the black cloth-covered record book with pencil attached were inseparable adjuncts to every lecture.

Among the many services Professor Bessey rendered to the teaching of botanical science that might be mentioned was the introduction in I 873 at Iowa Agricultural College of the laboratory method of instruc- 
tion with the use of compound microscopes. It is said that the laboratory method for advanced students was introduced at Harvard the year before, but this was wholly unknown to Bessey.

During the month of July, I88I, he gave the first course in botany in which laboratory work was offered at the University of Minnesota. He used to tell with much pleasure of reminiscence how he "carried the first compound microscopes to Minnesota." These instruments were borrowed from the college at Ames, for that particular session, since the University of Minnesota possessed no such microscopes at that time. There were none at Ames when he went there. Neither were there any at Nebraska when he went, there.

Bessey's students were numbered by the thousand and one of his greatest pleasures was to look over the lists of former students of his department and to picture them, oftentimes in distant lands, contributing of their thought and life for the betterment of mankind. Dozens of instructors in American schools and many investigators in the offices and laboratories of many institutions of learning and research owe their very life-ambition to the initial boost administered by Dr. Bessey at some critical moment. This was true not only of the botanically inclined but also of others whose primary inclination had drawn them into other fields. After a careful estimate made a few months before his death Professor Bessey came to the conclusion that in his forty-five years as a college professor he had had over 4,000 students in his classes. This was the work closest to his heart and in this he felt that he had fulfilled a divine commission. The love for young people and for the work of the teacher kept him young in spirit and vigorous in action to the end.

A large factor in moulding Bessey's standing as a botanist and in bringing him success as an educator was his series of text-books. In 1878 he began the preparation of a work on "Botany for High Schools and Colleges." The publishers had asked Dr. Gray to write this book, but he declined and recommended Professor Bessey. The manuscript was finished in January, I 880 , and the book appeared August I of that year. This text went through two later editions, one in $\mathbf{I} 88 \mathrm{I}$ and another in $\mathrm{I} 883$.

Then followed "The Essentials of Botany," the briefer course, of I884. This book, which went through seven editions, the last being in 1896 , enjoyed the enviable reputation as one of the most popular and most widely used texts in America. His last book, "The Essen- 
tials of College Botany" which he wrote (I9I4) with the assistance of his son, Dr. Ernst A. Bessey, was really another (the eighth) edition of the first elementary book.

At Nebraska, Bessey's ability as a college administrator was recognized at various times by the regents. At one time he was also acting president at Ames. He went to Nebraska as professor of botany and dean of the Industrial College. This deanship he held from I 884 to I 888 and again from I895 to I909, when he was made head dean. He was dean of the college of literature, science, and the arts from $\mathrm{I} 888$ to $\mathrm{I} 89 \mathrm{I}$. He was made acting chancellor of the university in the summer of I888, being called home from Europe, where he had gone with Mrs. Bessey to spend the summer in study. This position he held until I $89 \mathrm{I}$ when he succeeded in obtaining the appointment of Professor Canfield as chancellor. He was made

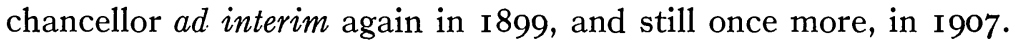

On December 25, I873, Charles E. Bessey was married to Miss Lucy Athearn of West Tisbury, Martha's Vineyard, Massachusetts. To them three sons were born: Edward, Ernst, and Carl. All of the sons graduated from the University of Nebraska. Edward and Carl specialized in electrical engineering. The former was assistant professor of electrical engineering in the Colorado Agricultural College at Fort Collins at the time of his death on July I2, I9ro. Carl is at present assistant chief engineer of the firm of Byllesby and Co., Chicago. Ernst specialized in botany and is at the present time professor of botany at the Michigan Agricultural College, his illustrious father's alma mater. Mrs. Bessey retains her home at I507 R Street, Lincoln.

The University of Nebraska, Lincoln.

\section{A Partial, List of Botanical Articles and Books Published by Charles E. Bessey ${ }^{1}$}

I87I. Natural science in common schools. Iowa Instructor and School Journal I2: 238-240. I87I.

Contributions to the flora of Jowa. Report to Board of Trustees Iowa Agricultural College for I87 I.

1872. Lemna polyrrhiza. Amer. Nat. 6: 636. 1872 .

I873. Directions for collecting mosses and lichens. Ames, Iowa. I873.

Sensitive stamens in Portulaca. Amer. Nat. 7: 464-465. 1873.

${ }^{1}$ I wish to thank Dr. Ernst A. Bessey for help in connection with the preparation of this sketch, also Professor T. J. Fitzpatrick for a number of titles that have been included in the bibliography.-R. J. P. 
1876. On a scientific course of study. Read before Iowa State Teachers' Association Dec. 28, 1876. Reprinted from The Aurora.

I877. The Erysiphei. Seventh Biennial Rep. Ia. Agr. Coll. I-r6. 1877 .

Observations on Silphium laciniatum, the so-called compass-plant. Amer. Nat. II: 486-489. 1877.

1880. The supposed dimorphism of Lithospermum longiflorum. Amer. Nat. 14: 4I7-42I. I880.

I881. A new species of insect destroying furlgus. Amer. Nat. 17: 1280-r28r. I $88 \mathrm{I}$.

Simblum rubescens Gerard, in Iowa. Bull. Torrey Club 8: 126. I88I.

A sketch of the progress of botany in the United States in 1880. Amer. Nat. 15: 947. I88I.

1882. The diseases of plants. Ia. State Hort. Soc. I882.

Some observations on the action of frost upon leaf-cells. Proc. Amer. Assoc. Adv. Sci. 31: 464-465. r 882.

The coffee-leaf fungus, one of the Mucedineae. Amer. Nat. 16: 584-586. I 882 .

The asparagus stem for laboratory study. Amer. Nat. I6: 43. I882.

1883. The periodical cicada in southeastern Massachusetts. Amer. Nat. 17: I070. 1883 .

1884. A suggestion in regard to the publication of new species. Amer. Nat. 18: $7 \mathrm{I}-72 . \mathrm{I} 884$.

A real Yankee puff-ball. Amer. Nat. 18: 530. I884.

Preliminary lists of Cryptogams of the Ames flora. Bull. Ia. Agr. Coll. Bot. I33-150. I884.

The wheat smuts. Bull. Ia. Agr. Coll. Bot. I I8-126. 1884.

The smut of Indian corn. Bull. Ia. Agr. Coll. Bot. 127-129. I884.

Adventitious inflorescence of Cuscuta glomerata. Amer. Nat. 18: I145II 47. I884.

The ergot. Bull. Ia. Agr. Coll. Bot. 130-132. I884.

The injuriousness of porcupine grass. Bull. Ia. Agr. Coll. Bot. II6-II8. I 884 .

Sexuality in the Zygnemaceae. Amer. Nat. I8: 42I-422. I884.

The rattle-box. Bull. Ia. Agr. Coll. Bot. I I I-I I5. I884.

Science and Practice. Ann. Rep. Nebr. State Board Agr. I884.

I885. The abundance of Ash-rust. Amer. Nat. 19: 886. I885.

Injurious fungi in their relation to the diseases of plants. Amer. Pomolog. Soc. $1885: 35$.

1886. The grasses and forage plants of Nebraska. Ann. Rep. Nebr. State Board Agr. I 886.

The rust of the ash tree (Aecidium Fraxini). Amer. Nat. 20: 806. 1886.

The roughness of certain uredospores. Amer. Nat. 20: 1053. 1886.

1887. Eastward extension of Pinus ponderosa in Nebraska. Amer. Nat. 21: 928. I 887.

A meeting-place of two floras. Bull. Torrey Club 14: 189-I9I. I887.

Westward extension of Juglans nigra in Nebraska. Amer. Nat. 21: 229. I 887 . 
The use of English names for fungi. Amer. Nat. 21: 264. I887.

The growth of Tulostoma mammosum. Amer. Nat. 21: 665. I887.

The ash-rust again. Amer. Nat. 21: 666. I887.

The study of lichens. Amer. Nat. 21: 666. I 887.

I888. The grass flora of the Nebraska plains. Amer. Nat. 22: I7I. I888.

First Annual Report of the Nebraska Agricultural Experiment Station. I 888.

1889. Report of the Botanist on the grasses and forage plants, and the catalogue of plants. (With H. J. Webber.) Ann. Rep. Nebr. State Board Agr. I 889.

Second Annual Report of the Nebraska Agricultural Experiment Station. I 889 .

The flora of the upper Niobrara. Amer. Nat. 23: 537-538. I889.

1890. The diseases of farm and garden crops. Nebr. Farmer 14: 89. I890.

Black knot. [Plowrightia morbosa (Schw.) Sacc.] Nebr. Farmer 14: 129. I 890 .

Stinking smut [Tilletia foetans (B. \& C.) Trel.]. Nebr. Farmer 14: I30. I890.

Grain smut [Ustilago segetum (Bull.) Dit.]. Nebr. Farmer 14: I5I. 1890.

Corn smut [U. maydis (D. C.) Cord.]. Nebr. Farmer 14: 165. I890.

Sorghum smut [U. sorghi (Link) Pers.]. Nebr. Farmer 14: I89. 1890.

The strawberry leaf spot, Ramularia Tulasnei Sacc. Nebr. Farmer 14: 209. I 890 .

Grain rust (Puccinia graminis Pers. and other species). Nebr. Farmer 14: 250. 1890 .

The rust of Indian corn (Puccinia sorghi Schw.). Nebr. Farmer 14: 293. I 890 .

The raspberry stem fungus. Nebr. Farmer 14: 333. 1890.

189I. A preliminary list of the grasses of Nebraska. Ann. Rep. Nebr. State Board Agr. I89r.

The bearberry in central Nebraska. Amer. Nat. 25: II30. I89I.

On the fertilization, crossing and hybridization of plants. Ann. Rep. Nebr. State Hort. Soc. 100-I I4. I891.

The hybridization of plants. Gard. \& For. 4: 466-467. I89r.

1892. A second report upon the native trees and shrubs of Nebraska. Ann. Rep. Nebr. State Hort. Soc. I54-185. 1892.

A preliminary description of the native and introduced grasses of Nebraska. Ann Rep. Nebr. State Board. Agr. 1892.

The rules of botanical nomenclature. (Rochester Rules.) Amer. Nat. 26: 860-86I. I892.

A second edition of Webber's "Appendix to the catalogue of the flora of Nebraska" with a supplementary list of recently reported species. Contr. Bot. Dept. Univ. Nebr. n. ser. o. I 892.

Transpiration, or the loss of water from plants. (With A. F. Woods.) Contr. Bot. Dept. Univ. Nebr. n. ser. 4. I892.

1893. Evolution and classification. Proc. Amer. Assoc. Adv. Sci. 43. 1893.

Fungous diseases of sugar beets. Rep. Nebr. Agr. Exp. Sta. 6. $\quad$ I893. 
The Russian thistle in Nebraska. Nebr. Agr. Exp. Sta. Bull. 31: 67-77. I893.

1894. The reforesting of the sandhills. Ann. Rep. Nebr. State Board Agr. I894.

Homologies of the Uredineae. Amer. Nat. 28: 989-996. 1894.

The botany of the apple tree. Ann. Rep. Nebr. State Hort. Soc. 7-39. r 894 .

Third report on the native trees and shrubs of Nebraska. Ann. Rep. Nebr. State Board Agr. I 894 .

Some facts in vegetable physiology related to problems in irrigation. Ann. Rep. Nebr. State Board Agr. 1894.

The structure of the wheat grain. Nebri Agr. Exp. Sta. Bull. 32: I00-1 Io. I 894 .

The structure and composition of bran.' Nebr. Agr. Exp. Sta. Bull. 32: I 10-I I4. I 894 .

1895. A protest against the "Rochester Rules." Amer. Nat. 29: 666-668. I895.

Notes on the distribution of the yellow pine in Nebraska. Gard. \& For. 8: 102-103. I895.

The botany of the grape. Rep. Nebr. State Hort. Soc. 7-26. I895.

The botany of the plums and cherries. Rep. Nebr. State Hort. Soc. 163I78. 1895 .

A preliminary list of the honey-producing plants of Nebraska. Nebr. Agr. Exp. Sta. Bull. 40: I4I-I52. I895.

1896. Were the sandhills of Nebraska formerly covered with forests? Publ. Nebr. Acad. Sci. 5: 7. I896. (Abstract.)

The origin of the flora of Nebraska. Publ. Nebr. Acad. Sci. 5: 33. I896. (Abstract.)

The box-elder on the plains. Gard. \& For. 9: 33. $\quad$ I 896.

The condition of forests and forestry in Nebraska. Proc. Amer. For. Assoc. II : $83-89$. I 896 .

Notes on the botany of the strawberry. Ann. Rep. Nebr. State Hort. Soc. I 896.

1897. Are the trees receding from the Nebraska plains? Gard. \& For. I0: 456457. I897.

The forage problem in Nebraska. Ann. Rep. Nebr. State Board Agr. I 897. The systematic arrangement of the Protophyta. Amer. Nat. 31: 63. I897. Erysiphe communis. -Bull. Torrey Club 24: 421. 1897 .

The phylogeny and taxonomy of the Angiosperms. Bot. Gaz. 24: 145-178. I 897 .

1898. The nomenclature of the Nebraska forest trees. Proc. Collect. Nebr. State Hist. Soc. II. 2. $\quad$ I 898.

Some facts in plant physiology bearing upon horticultural practices. Ann. Rep. Nebr. State Hort. Soc. 1898.

1899. The forests and forest trees of Nebraska. Ann. Rep. Nebr. State Board Agr. 1899.

The physiology of the apple tree. Ann. Rep. Nebr. State Hort. Soc. 1899.

1900. Some agricultural possibilities of western Nebraska. Ann. Rep. Nebr. State Board Agr. 1900. 
Vegetation of the sandhills. Ann. Rep. Nebr. State Board Agr. 1900.

The natural spreading of timber areas. Forester 6: 240-243. 1900.

The modern conception of the structure and classification of Diatoms, with a revision of the tribes and a rearrangement of the North American genera. Trans. Amer. Micr. Soc. 21: 6I-86. 1900.

One thousand miles for a fern. Asa Gray'Bull. 8: 2-6. 1900.

1901. A preliminary account of the plants of Nebraska which are reputed to be poisonous, or are suspected to be so. Ann. Rep. Nebr. State Board Agr. I90I.

Old world contributions to western orchards. Proc. Soc. Prom. Agr. Sci. 22. I90r.

Notes on the apple scab. Nebr. State Hort. Sqc. Bull. I. I90I.

More about fungus spores as bee-bread. Pl. World 4: 96. rgor.

The botanist's journey to the Denver meeting of the A. A. A. S. Science, n. ser. 24: 185-187. rgor.

Early winter colors of plant formations on the great plains. Science, n. ser. 24: $721-724$. I901.

The modern conception of the structure and classification of Desmids, with a revision of the tribes, and a rearrangement of the North American Genera. Trans. Amer. Micr. Soc. 22: 9I-96. I90I.

Baptisia tinctoria as a tumble-weed. Rhodora 3: 34-35. I901.

Home made wall charts. Journ. Appl. Micr. 4: II95. I90I.

1902. The structure and classification of the Conjugatae, with a revision of the families and a rearrangement of the North American genera. Trans. Amer. Micr. Soc. 23: 145-150. 1902.

A word as to indexes. Science, n. ser. 16: 476-477. 1902.

The morphology of the pine cone. Bot. Gaz. 33: 157-159. 1902.

Tree growing in Nebraska. For. \& Irr. 8: 453-456. 1902.

1903. List of Nebraska trees. Nebr. Park \& For. Man. I903.

Evolution in microscopic plants. Trans. Amer. Micr. Soc. 24: 5-12. 1903. The structure and classification of the Phycomycetes, with a revision of the families and a rearrangement of the North American genera. Trans. Amer. Micr. Soc. 24: 27-54. 1903.

Preliminary paper on diseases of grapes in Nebraska. Ann. Rep. Nebr. State Hort. Soc. I903.

Distribution of forest trees on the Nebraska plains. Atl. Slope Nat. I: 2 I. 1903.

1904. The classification of Protophyta. Trans. Amer. Micr. Soc. 25: 89-104. I904.

Notes on the agriculture of the Caucasus Mountains. Proc. Soc. Prom. Agr. Sci. 25. 1904 .

The chimney-shaped stomata of Holacantha emoryi. Bull. Torrey Club 31: 523-527. I904.

The grasses of Nebraska. Ann. Rep. Nebr. State Board Agr. I904.

Some foreign botanical gardens and parks. Ann. Rep. Nebr. State Hort. Soc. I904.

1905. Life in a seaside summer school. Pop. Sci. Monthly 80-89. 1905 . 
How much plant pathology ought a teacher of botany to know? Pl. World 8: $187-189 . \quad$ r 905.

Plant migration studies. Univ. Nebr. Stud. 5: II-37. I905.

The structure and classification of the lower green algae. Trans. Amer. Micr. Soc. 26: 121-136. 1905.

1906. The forest trees of eastern Menraska. Proc. Ia. Acad. Sci. I3: 75-87. I906.

The Carolina poplar. Ann. Rep. Nebr. State Board Agr. 1906-r907.

The growing importance of plant physiology in agricultural education. Proc. Soc. Prom. Agr. Sci. 27. I906. I

Twinned pistils in partridge pea. Amer. Bot. I7: 103. I9II.

Crop improvement by hybridizing wild species. Ann. Rep. Nebr. State Hort. Soc. I I 7-123. 1906.

City Trees. Ann. Rep. Nebr. State Hort. Soc. I53-157. 1906.

1907. Field work in botany in grammar and high schools. Nature study Review. 3: 9-16. I907.

A synopsis of plant phyla. Univ. Nebr. Stud. 7: 275-373. 1907 .

1908. The taxonomic aspect of the species question. Amer. Nat. 42: 218-224. 1908. (Also in Bot. Soc. Amer. Pub. 34: 21 8-224. 1908.)

Physiology of pruning. Nebr. State Hort. Soc. Bull. I8. 1908.

I909. The phyletic idea in taxonomy. Science, n. ser. 29: 81-roo. I909.

Outlines of plant phyla. Univ. Nebr. Dept. Bot. 1909, with two later editions with corrections and additions.

Laying the foundations. Annals of Iowa 9: 26-44. 1909.

I9I0. The phyla, classes and orders of plants. Trans. Amer. Micr. Soc. 29: 8596. I9ro.

Some European forest notes. For. Quart. 8: 20I-209. I9Io.

Selected rules of botanical nomenclature. (Especially for the use of foresters.) Univ. Nebr. For. Club Ann. 2. r9ro.

I9II. On the preparation of botanical teachers. Science, n. ser. 33: 633-639. I9I.

I913. Literature of North American Systematic botany. Univ. Nebr. For. Club Ann. 5. I9I3.

A preliminary paper on drought endurance. Ann. Rep. Nebr. State Hort. Soc. I9r3.

Tea growing in Transcaucasia. Pomona Coll. Journ. Econ. Bot. 3: 44I-445. I9I3.

Some of the next steps in Botanical Science. Science, n. ser. 37: I-13. r9i3.

1914. Synopsis of the conjugate Algae-Zygophyceae. Trans. Amer. Micr. Soc. 33: II -50 . I9I4.

Revisions of some plant phyla. Univ. Nebr. Stud. 14: 37-ro9. I9I4.

1915. The phylogenetic taxonomy of Flowering Plants. Ann. Mo. Bot. Gard. 2: ro9-r64. I9I5.

\section{Textbooks}

Botany for high schools and colleges. Henry Holt and Co. First edition r880; second edition $\mathrm{I} 88 \mathrm{I}$; third edition $\mathrm{I} 883$. 
The essentials of botany, briefer course. Henry Holt and Co. First edition 1884; second edition I885; third edition I886; fourth edition I889; fifth edition I892; sixth edition Feb. 7, I896; seventh edition July 23, I896.

Elementary botanical exercises for public schools and private study. Lincoln I892. Elementary botanical exercises and an elementary manual of Nebraska plants (second edition of above). Lincoln 1894 .

New elementary agriculture. (With Bruner and Swezey.) Univ. Publ. Co. I903. Elementary botany, including a manual of common genera of Nebraska plants. Univ. Publ. Co. Lincoln, I904.

Essentials of college botany. (With E. A. Bessey.) Henry Holt and Co. I9I4. 